He S Y, Wang B J, Wang G P, Wei Y.Rural livelihood transition and industrial development in protected areas: experience and inspiration. Acta Ecologica Sinica, 2021,41(23):9207-9215.

\title{
自然保护地社区生计转型与产业发展
}

\author{
何思源 ${ }^{1, *}$, 王博杰 ${ }^{1,2}$, 王国萍 ${ }^{1,2}$, 魏 钰 $^{3}$ \\ 1 中国科学院地理科学与资源研究所,北京 100101 \\ 2 中国科学院大学, 北京 100049 \\ 3 中国科学院科技战略咨询研究院, 北京 100190
}

摘要: 良好的社区与自然保护地关系首先建立在社区生计的公平与可持续发展上。为促进社区认同、接受乃至参与自然保护地 建设与管理,我国自然保护地管理逐渐重视社区利益,推动其生计转型发展与生态保护相协调。社区居民从事产业活动、进行 生产经营、参与产业分工, 是维持和改善生计的重要方式之一。研究采用质性内容分析方法,从不同研究视角、地理空间和政策 背景的案例研究中提取自然保护地社区生计转型及其产业发展路径的内在逻辑,形成内容、激励机制、政策保障、结果、成败分 析、发展对策六个核心范畴, 以动因与形式、结果与原因来归纳总结前 5 个范畴的核心事实,根据发展对策提出自然保护地社区 生计转型和产业发展原则,并结合国家公园特征和管理目标提出建议。研究表明,在社区层面协同保护与发展本质上来说是降 低农户面临的自然、政策和市场风险的过程,生计可持续性和公平性双重目标可以通过产业生态化,产业部分替代或完全替代 来实现。以产业发展带动生计转型具有经济、社会、文化多重效益,但其实现需要尊重本土文化,保障社区基本权利,多方参与 协作, 匹配和提升居民差异化能力。在国家公园体制建设中社区生计发展特别需要依托本地资源, 对标市场需求, 推进产业生 态化,拓展传统产业功能,从自然和半自然生态系统的协同中寻求生态和文化价值向经济价值转化。

关键词: 自然保护地;社区生计;生态补偿;生态移民;国家公园

\section{Rural livelihood transition and industrial development in protected areas: experience and inspiration}

\author{
HE Siyuan ${ }^{1, *}$, WANG Bojie ${ }^{1,2}$, WANG Guoping ${ }^{1,2}$, WEI Yu ${ }^{3}$ \\ 1 Institute of Geographic Sciences and Natural Resources Research, Chinese Academy of Sciences, Beijing 100101, China \\ 2 University of Chinese Academy of Sciences, Beijing 100049, China \\ 3 Institute of Science and Development, Chinese Academy of Sciences, Beijing 100190, China
}

\begin{abstract}
A healthy community-protected area relation essentially relies on the fair and sustainable development of rural livelihood. In order to promote community's approval, acceptance of, and participation in the construction and management of protected areas, authorities gradually set store on community interest and continue complying livelihood transition with conservation. However, it is an under-explored domain that how community livelihood development progressed across different protected areas in China, especially when regional industry development is an important way of maintaining and improving rural livelihood because community people are actively engaged in diverse industry practice, managing production and operation, and participating in industry division. This research uses qualitative content analysis to induce the inherent logic of rural livelihood transition and industrial development of protected areas from case studies of different perspectives, geographic locations and policy background. Research papers were firstly searched in the CNKI journal database with the
\end{abstract}

基金项目: 国家自然科学基金项目 (42001194) ; 国家林业和草原局国家公园传统产业转型发展专题研究( JYCL-2020-00039)

收稿日期: 2020-12-08; 网络出版日期:2021-07-24

*通讯作者 Corresponding author.E-mail: hesy@igsnrr.ac.cn, 
Research Topic covering “community”, “livelihood” and “conservation” as at the same time. Only case studies of protected areas were selected and cases without enough information of livelihood transition or industrial development were further omitted. In total, 28 paper were used and about 30 cases were reviewed, covering a time range of 30 years and including different ecosystems. A grounded theory approach has been followed to produce six core categories of content, incentives, policy guarantee, outcomes, success/failure analysis, and development countermeasures. The relations among these categories have formed a dynamic pathway of community livelihood transition in the protected areas. Each of the categories has related concepts and facts to support this category. The core facts of the first five categories are summarised to motivation and forms, and outcomes and their causes. The sixth category is developed to provide principles of community livelihood transition and industrial development in protected areas. Finally, some suggestions are put forward to national park management according to its features and objectives. Research reveals that coordinating conservation and development at community level is basically a process of risk reduction, during which natural risks, policy risks and market risks should be controlled for rural households. The dual aims of sustainable and fair livelihood are realised through ecologicalisation of industries, partial substitution of industries or complete substitution. Results show that livelihood transition facilitated by industrial development can lead to not only economic benefits but also social and cultural benefits. However, to fully achieve these benefits, authorities should respect local culture, guarantee land use right of rural households, and encourage multiparty participation to allocate resources and activate market and civil power. Thus, policies and projects can be designed and implemented to match individuals and households with different capabilities, and capacity building is a more targeted process other than a universal one. During the construction of national parks, community livelihood development should rely on local resources, carter to market demands, promote industry ecologicalisation and expand traditional industrial functions. The final objective is to enhance transition of ecological and cultural values to economic values through a collaborated artificial and natural system.

Key Words : protected area; community livelihood; eco-compensation; eco-migration; national park

我国 2015 年启动国家公园体制试点工作,探索适合中国自然保护与社会经济发展的国家公园管理体制, 有序建立以国家公园为主体的自然保护地体系 ${ }^{[1]}$ 。从 20 世纪 80 年代开始,在反思“堡垒式”保护中, 自然保 护领域开始重新认识社区与自然保护地的关系。首先, 在时间上,社区往往早于自然保护地建立而存在, 经历 长期的自然适应,对自然资源和土地利用管理形成了一定的传统方式; 其次,在空间上,由于社区生计往往依 赖于自然资源, 农牧业等传统产业形式居多, 因此自然保护地能够为社区提供资源, 而社区生产和生活空间也 可以以半自然、低影响的方式联通自然保护地,促进景观尺度的整体保护 ${ }^{[2-3]}$; 第三, 在管理上,社区参与自然 保护管理能够减少冲突, 改善自然保护地管理成效 ${ }^{[4-5]}$ 。因此, 自然保护地建设和管理开始重视当地社区和 居民的支持和参与, 并认为自然保护应为社区带来社会和经济收益 ${ }^{[6-7]}$, 将自然保护地社区生计与保护目标 协同发展视为 “以人为本” 的自然保护的目标 ${ }^{[8]}$ 。

可持续生计研究将生计定义为个人或家庭所拥有和获得的、能用于谋生和改善长远生活状况的资产、能 力和活动的集合 ${ }^{[9]}$, 而自然保护地社区居民从事产业活动、进行生产经营、参与产业分工, 是维持和改善生计 的重要方式之一 ${ }^{[10]}$ 。研究表明, 自然保护地的建立会限制林业、渔业资源收获和经营, 限定种养殖业范围、方 式和强度, 规范准人产业, 从而造成社区居民生产经营受限、收人降低、工作机会减少等生计影响 ${ }^{[5,11-13]}$; 同 时,随着“以人文本”的自然保护理念发展, 为了减轻以农业 (包括种植业、林业、畜牧业和渔业等) 为代表的传 统产业生产的环境压力, 同时尊重社区传统生计, 各国政府都在制定生态化的产业发展政策,推动自然保护地 农业生产生态化, 为生态产品和服务创造激励和市场, 从而鼓励农户就地参与兼容生态保护管理目标的生产 经营,包括农林牧渔业生态化生产、参与生态旅游服务供给、发展增值性手工业、参与生态系统管护等 ${ }^{[13,14-17]}$ 等, 让社区在产业生态化、产业类型拓展中实现生计转型 ${ }^{[18-19]}$ 。因此, 从可持续生计视角看, 自然保护地管理 
中的资源管控和面向保护目标的区域产业政策,都会影响社区居民生计资本构成、数量和质量,在政策保障、 市场导向、社会参与等共同作用下促使社区居民选择产业发展方式、参与产业分工、进人新产业领域,以产业 途径发展多元生计和替代生计。

我国国家公园在空间上整合多类型保护地,涉及到周边诸多社区及居民的生产生活,社区产业活动对国 家公园具有直接的生态影响。在保护管理目标制约下,社区从事的产业类型影响国家公园自然保护目标的实 现 ${ }^{[20]}$ 。面对国家公园生态保护与全民公益的管理目标, 必须寻求社区可持续生计与保护目标的协同发展理 论依据与实现路径。大量研究表明,我国自然保护发展历程中,无论是实施宏观生态保护政策还是规划和管 理各类型的自然保护地,都在逐步重视对生态政策所影响的社区进行产业指导,拓宽社区享受生态保护红利 的途径, 提升其受益能力, 促进其生计转型与生态保护相协调, 在实现生态保护的公共利益时保障当地社区公 平受益与可持续发展。当前对自然保护地社区生计转型及其产业发展途径的案例研究日益丰富: 研究视角多 样,包括政策成效 ${ }^{[21-23]}$ 转型动机 ${ }^{[11,24-25]}$ 、社区感知 ${ }^{[26-28]}$ 多方面; 涉及地域广泛, 涵盖森林、草原、湿地、荒漠等 国土东中西典型生态系统类型 ${ }^{[22,24,29-30]}$; 政策背景丰富,包括自然保护地建立和管理 ${ }^{[10]}$, 生态奖补 ${ }^{[23]}$ 、精准 扶贫 ${ }^{[31]}$ 、退耕还林/草/湿 ${ }^{[30]}$ 等政策。不过, 这也表明当前的案例研究相对分散, 缺乏一个系统地理论化地整 理和提升。因此,本文以历史视角研究我国自然保护地管理过程中社区生计转型及其产业发展路径,采用质 性内容分析方法提取不同研究视角、地理空间和政策背景下自然保护地社区生计转型中产业发展的内在逻 辑, 归纳总结核心事实, 提出自然保护地社区生计转型及其产业发展原则, 并尝试以此原则指导国家公园社区 生计转型与产业发展。

\section{1 研究方法}

\section{1 数据获取}

研究从中国知网学术文献数据库为数据来源, 初步以文献主题同时涵盖“社区” “生计”与 “保护”篮选文 献, 对每篇文献阅读其标题和摘要, 首先删除仅针对乡村社区减贫发展, 但不涉及各类型自然保护地周边农户 生计发展具体案例的研究; 其次粗读其内容, 删除虽然是自然保护地社区案例研究,但不能反映当地居民生计 转型中产业发展具体过程的研究。研究最终选择文献 28 篇, 时间跨度约 30 年(1999-2020 年), 以自然保护 区为主,涉及不同自然保护地近 30 个。

\section{2 数据分析}

由于符合研究目的的文献数量有限但案例本身具有代表性,本文尝试用质性内容分析对我国自然保护地 周边社区生计转型和产业发展状况进行探索性研究, 对不同案例研究的文本内容进行识别和编码, 将大量的 文本归类为代表相似意义的有效范畴, 从而形成对自然保护地周边社区生计转型和产业发展的深层认识 ${ }^{[32]}$ 。 研究采用常规质性内容分析路径, 这一分析路径适用于 所研究的现象相关理论或文献较为有限,研究者避免使 用预设范畴, 而是让范畴及其名称从数据中自然浮 现 ${ }^{[33]}$ 。因此,其数据编码过程借鉴扎根理论方法的应 用,在分析之前仅有对自然保护地社区生计转型和产业 发展问题的兴趣, 但没有具体的假设, 要通过归纳文本 内容来不断自下而上地提炼研究问题。

根据文献文本内容精读和编码, 得到自然保护地生 计转型和产业发展内容、激励机制、政策保障、结果、成 败分析、发展对策 6 个范畴,每个范畴下存在相关的子 范畴。这 6 个范畴形成自然保护地生计转型和产业发 展的动态路径(图 1)。

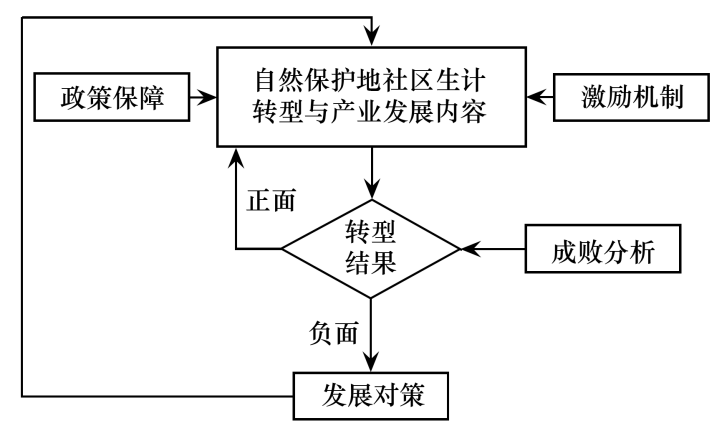

图 1 自然保护地生计转型和产业发展的动态路径

Fig.1 Dynamics of livelihood transition and industrial development in protected areas 
在得到这一动态路径的基础上,研究对 6 个范畴的支撑内容进行详细解读,并以发展对策范畴为基础, 结 合整体动态路径分析, 提出自然保护地社区生计转型和产业发展基本原则,并将其进一步演绎到国家公园体 制建设进程中。

\section{2 历史视角的自然保护地社区生计转型与产业发展}

\section{1 动因与形式}

从自然保护发展历程看,我国自然保护地社区生计转型与产业发展动因可以从两个视角来看:

其一,生态工程与生态建设政策视角下的自然保护地社区居民的生计可持续发展。社区产业活动一般存 在与自然保护目标的背离,社区不一定存在现实的贫困,但对资源的消耗使生计存在不可持续风险;

其二,减贫脱困政策视角下的自然保护地社区居民的生计公平。社区产业活动可能并不背离自然保护目 标, 但因发展限制会陷人持续贫困而失去公平发展机会。

为促进生计可持续发展和实现生计公平,自然保护地可以采用生态移民转产与就地生计发展两种形式。 其中,生态移民转产以草原地区为典型,如三江源自然保护区核心区禁牧移民工程,它规定草场家庭承包政策 长期不变, 但暂停牧民承包草场的使用权,牧民迁出承包草场并在城镇定居, 其产业转型主要为从事种植业、 养殖业、畜牧业、低级服务业等 ${ }^{[21,24,34]}$ 。

就地生计发展因自然保护地自然资源禀赋、民族文化特征、宏观产业政策等差异性而呈现出多样化,从生 计策略角度看主要呈现三种类型 (表 1)。一是产业持续生态化,从种养殖结构、规模、投人-产出-废物处理流 程等方面将产业活动控制在生态环境承载力之内 ${ }^{[21,35-44]}$; 二是产业的部分替代化, 以传统农林牧渔的生态化 为基础, 通过参与其他产业而增强生计多样化 ${ }^{[21,24,39,42-47]}$; 三是产业的完全替代化,一般表现为对原有农业产 业活动的放弃而全面投人上述非农产业活动 ${ }^{[11,21,23,34-35,48]}$ 。

表 1 自然保护地社区就地生计策略与代表产业活动

Table 1 Community in-situ livelihood strategy and representative industrial activities

\begin{tabular}{ll}
\hline 生计策略 & 代表方式 \\
Livelihood Strategy & Representative Industry \\
\hline 产业持续生态化(生计多样化) & 精细循环农业、复合农林系统、生态林业、经济林结构调整、减畜和生 \\
Ecologisation (livelihood diversity) & 态建设导向的生态牧业;中药材、茶叶经济作物生态化基地等 \\
产业部分替代(生计多样化) & 产业生态化基础上参与:手工业,旅游餐饮、旅游服务,生态管护,精深 \\
Partial Substitution (livelihood diversity) & 加工等其他产业活动 \\
产业完全替代(替代生计) & 全面投人农业外的其他产业 \\
Total Substitution ( substitute livelihood) & \\
\hline
\end{tabular}

\section{2 结果与原因}

\subsection{1 激励机制与保障措施}

为促进自然保护地社区生计发展与生态保护相协同,政府会出台一系列政策来推动社区产业发展以进行 生计转型 (表 2)。其激励机制包括物质和非物质两方面,其保障措施主要从社会福利保障、产业组织保障和 能力提升保障来降低社区风险。

表 2 自然保护地社区生计发展的激励机制与保障措施

Table 2 Incentives and guarantees of community livelihood development

\begin{tabular}{|c|c|c|}
\hline & $\begin{array}{l}\text { 激励机制 } \\
\text { Incentives }\end{array}$ & $\begin{array}{l}\text { 保障措施 } \\
\text { Guarantees }\end{array}$ \\
\hline $\begin{array}{l}\text { 政策内容 } \\
\text { Policy Content }\end{array}$ & $\begin{array}{l}\text { 物质激励:生态奖补、生活补贴、生态管护补贴、税费减 } \\
\text { 免、优惠信贷 } \\
\text { 非物质激励:生态保护荣誉、文化倡导 }\end{array}$ & $\begin{array}{l}\text { 社会福利: 基础设施、公共服务设施资金和项目,社会保险 } \\
\text { 产业组织:农村社会服务与生产组织建设、市场信息和营 } \\
\text { 销渠道拓展、社区发展基金等 } \\
\text { 能力提升:环境与市场意识教育、技术培训等 }\end{array}$ \\
\hline
\end{tabular}




\subsection{2 结果与问题}

在上述多元政策激励与保障下,自然保护地社区生计转型过程与结果因地而异。基于多案例进行内容分 析,研究发现,正面成效主要体现在三个方面。一是在推动生计转型的宣教中,社区居民的生态保护意识、文 化传承意识与自然资源管理的自觉性得到强化,提高了社区参与发展事务的意识,特别是提升了弱势群体的 话语权; 二是促进社区建立管理与生产合作组织,或提升已有组织在促进社区发展、自然资源管理和社区生态 建设方面的能力;三是通过产业的生态化和替代产业的发展提高居民总体收人水平。

不过,研究也发现生计转型中三个典型问题。一是以草原生态系统和民族地区为代表,因传统生产方式 丧失导致明显的种质资源流失和文化消亡 ${ }^{[37]}$; 二是尽管居民收人短期内上升,但在长期发展中, 特别是生态 补偿政策波动中, 收人上升不可持续甚至下降 ${ }^{[22-24]}$; 三是生态移民转产长期看来存在转产岗位不足、转产失 败、移民回流、贫富差距增加等问题 ${ }^{[21,34]}$ 。

\subsection{3 原因分析}

不同的学者从产权理论、福利经济学理论、需求理论、行为经济学理论、能力理论等不同视角,试图寻找有 利于产业生态化、生计多元化和替代生计发展的因素。通过质性内容分析发现三个有利因素。

第一是利益相关方广泛参与。农户、政府、自然保护地管理部门、社会组织、企业等多方参与,有利于发展 适宜的产业组织形式进行规模化、标准化生产经营、降低市场风险。

第二是社区具有主观能动性。主动寻求能力发展, 具有示范带头人以及活跃和成熟的社区经营组织等, 有利于社区分享保护权和发展权。

第三是灵活依托市场机制。以自然保护地产品与服务的稀缺性、唯一性和独特性来对接消费需求所追求 的生态化、特色化,有利于高效地配给资源和针对性地进行能力提升。

因此, 自然保护地社区生计转型和产业发展成功不可缺少是社区的内生动力, 市场的外部驱动与利益相 关方对两者的对接。

相对的,研究对生计转型及其产业发展路径诸多问题背后的原因予以凝练,将案例研究总结为四个层面。

其一是缺少发展激励, 发展思路割裂了人地关系。比如,生态移民转产失败可能是忽视了原住民长期以 来建立的人与自然生态系统的平衡 ${ }^{[21]}$; 一些替代产业缺乏当地人的文化认同,甚至导致社区文化身份最终丧 失 ${ }^{[48]}$; 农林牧渔业往往是传统生计的核心, 脱离草场、耕地等生产资料导致原有生计链条中的副产品、经济作 物、粮食等缺失, 日常采购成本大幅提高 ${ }^{[28,34]}$ 。

其二是发展保障不足,政策与市场风险尚未得到有效的应对。政策风险首先表现为生态补偿缺乏科学 性、空间差异性和时间动态性,市场机制不发达,与产业政策不接轨 ${ }^{[11,21-22]}$ 。其次,产业转型发展资金机制不 完善:部门主导的产业发展往往依赖于生态补偿经费和部门营业收人, 缺乏协调保护与发展的专项补偿资金, 如人兽冲突补偿 ${ }^{[42]}$; 非政府组织协调与社区主导的产业发展依赖于自筹资金, 不确定性高 ${ }^{[41-42]}$ 。从市场风险 看,市场知识储备不足、市场信息获取能力低下等原因导致社区个体农户在参与市场竞争时对市场价格波动、 市场需求变化等因素难以把握和应对 ${ }^{[36,42]}$; 小农与产业组织融合不深让生态产品与服务难以进行统一、标准 化监管,使区域生态农产品、旅游服务等面对市场竞争时难以胜出 ${ }^{[42,49]}$ 。

其三是发展基础受损,土地权属和规模影响了社区居民的获益能力和公平性。自然保护地管理过程中的 退耕还林、封山育林、退牧还草等政策虽然不改变集体土地所有权和承包权,但其使用权与实际收益权已经丧 失或部分丧失,存在事实上的 “失地” 和土地产权权益的扭曲,接受生态补偿和离土打工等能够在短期带来收 人的提升,但其集体产权管理权的丧失会导致基于权利的获益能力不断压缩 ${ }^{[11,46]}$ 。从长期成效看,短期收人 提升不可持续, 土地规模较大的农户还会因为过高的补偿收人产生休闲需求效应而不利于产业转型发 展 ${ }^{[23,37,43]}$; 同时, 自然保护地乐于开展生态旅游转型发展,但在旅游经营权转让中,社区因集体产权管理权的 丧失而不具有旅游利益分配谈判权利 ${ }^{[46]}$ 。

其四是主体能力不足,社区居民的能力和个体差异不足以应对产业生态化和多元化的要求。案例研究表 
明,语言、文化水平、技能程度、年龄、生活习俗等方面强烈制约个人通过产业转型来拓展生计,低端行业就业 难以促进产业整体发展和生计可持续,而技能培训与就业帮扶尚显不足,在农副产品加工业、生态农业畜牧 业、特色旅游业和服务业等方面都存在制约 ${ }^{[21,24,34,42]}$ 。此外,社区整体能力的不足让居民难以有效参与自然 保护地管理规划, 在产业发展上不能有效的表达诉求, 以示范户、示范点开展的生计转型面临复制和推广困 难 ${ }^{[35-36,41,44,48]}$ 。同时,农户在家庭年龄结构、文化水平、既有生计策略等方面的差异, 使得同一区域存在生计 发展的选择偏好, 统一的产业转型缺乏针对性 ${ }^{[43]}$ 。

\section{3 自然保护地社区生计转型与产业发展原则与启示}

\section{1 自然保护地社区生计转型与产业发展原则}

针对当前自然保护地社区生计转型和产业发展现状与动因,学者针对不同区域的具体问题提出了内容广 泛的对策, 本文通过质性内容分析将其凝练为以下原则, 使其既具有一定的普适性, 也能够针对自然保护地具 体情况发展具体对策。

首先, 自然保护地社区生计转型和产业发展理念要根植于本土文化。不少乡村社区传统产业是本土文化 的一部分。一方面,在生产实践中所积累的知识、技术、制度和信仰等传统生态知识富有生态保护思想、有意 或无意中贡献于生态保护; 另一方面, 经由这些传统生态知识作用而生产的物质产品、非物质文化遗产和景 观, 具有稀缺性和独特性。因此, 社区生计发展需要在产业生态化上进一步挖掘传统知识与现代生态理念的 结合点, 维持和优化产业结构, 提高产品的生态和文化附加值, 推进品牌建设; 也需要从多元化的产业类型, 如 民族手工业、农副产品精深加工业、旅游导赏、旅游服务等方面将本土自然和文化资源产品化、商品化, 就地吸 纳农村劳动力参与产业分工。

其次,自然保护理念要融入社区生计发展。自然保护地社区生计发展不是以脱贫为唯一目的的发展,而 要将自然保护地管理作为发展的优势条件和发展契机, 是保护权和发展权共享。因此, 体现自然保护的正外 部性的生态补偿不应当是一个被动的利益分配机制, 而应成为促进产业转型发展的动力。第一,生态补偿应 以多元化形式反映社区生态保护行为的生计成本, 体现以户为单位的生计资本差异, 强化人兽冲突的损害赔 偿,设立生态管护岗位等间接补偿模式; 第二,生态补偿款项应当成为生计发展的原始资金, 设置生态补偿上 限来节约部分原有对大规模土地拥有者的补偿经费转而建立优惠信贷、产业扶持基金等。第三,生态补偿需 要配套明确的产业转型发展措施, 与教育、医疗等社会保障相衔接, 从而确保其长期的激励作用和产业培育 需求。

第三,要全面提升社区的主体地位和综合能力。社区以产业发展促进生计转型时,个人、家庭、社区组织 在产业转型发展规划、执行、监督、评估与改进过程中应具有充分的发言权,在保护管理中成为平等的合作伙 伴。社区特别需要在土地产权处置上具有发言权, 能够就集体土地的使用权、收益权等在符合法律依据、不违 背保护目标的情况下与政府等利益相关方进行商榷, 能够在承包土地的使用权、经营权、收益权、收益处置权 和使用权的转让权或流转权上在法律和管理要求内自由裁夺。社区也需要获得与所认可的生计转型相匹配 的能力。在个体农户层面, 在短期要相对重视职业技术培训,在长期要重视乡土、生态和产业发展观念和管理 能力; 在社区层面,其能力建设主要针对社区生产经营和管理组织开展, 提升其应对市场风险、把握市场脉络 等能力, 促进小农与产业组织融合发展, 完善村规民约的制定、实施、监测以提升资源管理的制度化、规范化、 长效化。

第四, 利益相关方权责分明, 因地制宜地以可行方式充分协作。从降低生计风险, 提高生计可持续性与生 态保护效率的角度看,农户、社区组织、保护地管理部门、当地政府、企业、民间组织等这些利益相关方必须各 司其职,整合联动, 才能发挥自然保护地本土资源优势, 推动形成可持续的产业链和生计方式, 达到生态保护 与社区生计发展的双赢。政府提供切实可行的产业政策,产业发展政策与生态保护政策相互协调而且面向长 远目标, 如制定产业生态标准, 建立生态标识体系, 优化产业发展环境; 农户与合作经营组织、企业进行产业组 
织融合, 优化资源配置以实现生态化生产, 品牌化建设和经济附加值提升; 非政府组织提供资金、技术和能力, 提升社区生产经营能力; 自然保护地管理机构提供理念和平台来整合多元资金与资源为产业发展牵线搭桥, 实施和监督生态补偿与产业政策。

3.2 对国家公园社区生计转型与产业发展的启示

自然保护地具有明确的生物多样性与生态系统保护目标, 因此, 当地社区不同于一般乡村地区,其发展权 利与生态保护责任义务并行,发展无法脱离保护地管理建设。在这一点上,国家公园也不例外。同时,国家公 园作为对大规模生态系统进行保护的自然保护地,从其管理目标和体制建设进程看,也具有其特征。

首先,国家公园体制试点在空间上整合原有保护地,强化生态系统完整性保护,使得社区生产生活空间与 国家公园边界和分区有了新的互动,生计活动的过程与后果也需要重新对标国家公园分区管理的正面负面清 单与总体管理目标进行评判。

其次,国家公园具有国家代表性,保护最典型和最具有价值的自然生态系统、景观与文化遗产,这也为社 区重新定位自身与环境的关系,发掘自然与文化的融合及其价值实现带来了契机。

因此,国家公园相对较大的空间范围与人口规模因社区间的社会经济文化差异,带来区域内社区生计与 转型路径的多样化和复杂性,而其管理体制的优化和管理目标多样化,也会因利益相关方的多元化、政策创 新、法律强化、就业门类增加等为社区生计带来新的契机。

基于对国家公园的这一认识,结合以上对自然保护地社区生计转型与产业发展的整体解读,本文提出国 家公园社区发展应继承既往优良经验,把握新的机遇, 从下述方面开展实践:

社区生计转型和产业发展理念与实践不要脱离本土文化。产业生态化、类型多样化与替代产业发展都要 尽量尊重和符合本土文化,力求实现文化附加值。

自然保护观念要贯穿产业发展过程。产业发展目标、技术路径、管理体系、产品与服务都要直接或间接依 托生态经济理论,依赖自然保护成果, 支持自然保护管理,让保护对象与保护结果成为优质的生计资本,让国 家公园品牌成为产业发展机遇。

产业活动要具有时空匹配性。对标国家公园生态系统完整性管理, 从景观尺度出发协调产业活动空间布 局,匹配国家公园不同位置的社区能力和需求; 通过长期的社区能力建设、产业组织融合、市场培育等来适应 景观尺度上不同社区之间、乡村与城镇之间的产业链构建和产业布局。

社区主体地位和民间组织能力要得到充分运用。在协同保护与社区发展的实践中,应重视社区精英的示 范与带动作用,农户间联动与资源管理自组织能力, 社区生产经营组织联动外部市场抵御风险等作用。随着 多方参与理念的认可和实践,应特别重视利用民间组织的资金、技术和能力来进一步推行社区赋权和能力建 设,提升社区主体地位。

社区产业发展要有明确的市场导向。市场需求的生态化、定制化被认为是自然保护地产品与服务发展的 重要契机,在明确的需求导向下,政府与民间机构等要帮助分析需求的时空差异,建立产品与服务标准,形成 符合资源属性和市场属性的生产周期,充分为社区产品创造市场进人机会和提升竞争能力,也避免商品导向 的资源掠夺。从社区到消费者这一链条中, 要依托现代科技和新兴技术来开展采集、加工、储存、运输、营销, 联动利益相关方构建利益分配等相关机制。

\section{4 结论与讨论}

本文使用质性内容分析方法, 对近 30 个自然保护地内社区生计转型和产业发展研究进行综述,构建了自 然保护地生计转型和产业发展的动态路径并对其核心范畴进行解读。研究得到以下主要结论:

(1) 自然保护地社区生计发展目标在协同生态保护和区域发展时具有可持续性和公平性双重目标,一般 以生态移民转产与就地生计发展来实现, 具有产业持续生态化,产业的部分替代化和产业的完全替代化三种 主要实施路径。 
(2) 自然保护地社区生计转型与产业发展成效不仅体现在家庭收人等经济效益上,也体现在社区管理能 力提升、生态文化意识强化等社会效益上,使得社区产业发展带动生计转型成为自然保护地管理多重成效的 体现。

（3）自然保护地社区产业需要政府统筹区域产业布局,以尊重本土文化,保障社区土地和资源权利为基 础,确保政策的多元、持续和稳定; 连同市场引导、社会力量帮扶,让产业发展匹配社区居民差异化资本、有针 对性的提升必要资本和能力; 尊重社区在发展中的主体地位,避免 “一刀切” 的盲目转产带来的经济、文化乃 至生态的不可持续。

(4) 国家公园社区发展需要依托本地资源和本土文化,对标市场需求,推进产业生态化,拓展传统农牧业 功能,逐步形成对自然与半自然生态系统功能的维持和对具体景观资源的合理使用, 寻求生态和文化价值向 经济价值转化。

在自然保护地区域内确保社区生计公平和可持续发展, 通过生计转型来实现自然保护目标与生计发展双 重目标, 从本质上来说是一个降低农户生计风险的过程 ${ }^{50]}$ 。因此,生计转型的原则就是在自然保护地的保护 管理目标下通过多方协作实现社区人地关系的高水平平衡, 而社区居民开展特定产业、参与产业分工、选择生 产和经营方式, 是中观层面产业发展在微观层面农户生计的具体体现, 使得产业活动成为多方协作、统筹调配 资源、联动自然与社会经济的重要生计方式。总体而言, 吸收利用传统生态知识, 以现代生态科学理念和技术 进行生产,在生态环境承载力内进行产业发展,才能降低生计发展的自然风险; 在自然保护地局地尺度上,将 生态保护政策,特别是生态补偿政策与产业发展政策进行长期的协同匹配,才能减小政策预期的不明朗,降低 生计发展的政策风险; 充分利用现代市场机制, 构建适宜的产业组织模式, 加强产品与服务差异化, 发展包含 政府补贴、金融保险工具在内的多元长效风险补偿机制,才能降低产业发展的市场风险。

\section{参考文献 (References) :}

[ 1 ] 虞虎, 钟林生. 基于国际经验的我国国家公园遴选探讨. 生态学报, 2019, 39(4)：1309-1317.

[ 2 ] He S Y, Yang L F, Min Q W. Community participation in nature conservation: the Chinese experience and its implication to national park management. Sustainability, 2020, 12(11): 4760 .

[ 3 ] Kshettry A, Vaidyanathan S, Sukumar R, Athreya V. Looking beyond protected areas: identifying conservation compatible landscapes in agroforest mosaics in north-eastern India. Global Ecology and Conservation, 2020, 22: e00905.

[ 4 ] Abukari H, Mwalyosi R B. Local communities' perceptions about the impact of protected areas on livelihoods and community development. Global Ecology and Conservation, 2020, 22: e00909.

[ 5 ] 何思源, 魏铎, 苏杨, 闵庆文. 保障国家公园体制试点区社区居民利益分享的公平与可持续性一一基于社会-生态系统意义认知的研究. 生态学报, 2020, 40(7) : 2450-2462.

[ 6 ] Adams W M, Hulme D. If community conservation is the answer in Africa, what is the question? Oryx, 2001, 35(3) : $193-200$.

[ 7 ] Torquebiau E, Taylor R D. Natural resource management by rural citizens in developing countries: innovations still required. Biodiversity and Conservation, 2009, 18(10): 2537-2550.

[ 8 ] Western D, Pearl M C. Conservation for the Twenty-First Century. New York: Oxford University Press, 1989.

[ 9 ] Chambers R, Conway G R. Sustainable Rural Livelihoods: Practical Concepts for the 21st Century. IDS Discussion Paper 296, Brighton: IDS, 1992.

[10] 陈传明, 侯雨峰, 吴丽媛. 自然保护区建立对区内居民生计影响研究一一基于福建武夷山国家级自然保护区 272 户区内居民调研. 中国 农业资源与区划, 2018，39(1)：219-224.

[11] 宋文飞, 李国平, 韩先锋. 自然保护区生态保护与农民发展意向的冲突分析一一基于陕西国家级自然保护区周边 660 户农民的调研数 据. 中国人口・资源与环境, 2015, 25(10): 139-149.

[12］杨彬如. 自然保护区居民生计资本与生计策略. 水土保持通报, 2017，37(3)：113-118，124-124.

[13] Capistrano R C G, Charles A T. Indigenous rights and coastal fisheries: a framework of livelihoods, rights and equity. Ocean \& Coastal Management, 2012, 69: 200-209.

[14] Homewood K M. Policy, environment and development in African rangelands. Environmental Science \& Policy, 2004, 7(3): 125-143.

[15] 王瑾, 张玉钧, 石玲. 可持续生计目标下的生态旅游发展模式一以河北白洋淀湿地自然保护区王家寨社区为例. 生态学报, 2014,34 
(9) : 2388-2400.

[16] 赵翔, 朱子云, 吕植, 肖凌云, 梅索南措, 王吴. 社区为主体的保护: 对三江源国家公园生态管护公益岗位的思考. 生物多样性, 2018, $26(2): 210-216$.

[17] Bluwstein J. From colonial fortresses to neoliberal landscapes in Northern Tanzania: a biopolitical ecology of wildlife conservation. Journal of Political Ecology, 2018, 25(1): 144- 168.

[18］王真, 王谋. 自然保护区周边环境友好型农业产业组织模式演进分析一一朱䰹保护区为例. 生态经济, 2016, 32(12): $192-197$.

[19] Tao T C H, Wall G. Tourism as a sustainable livelihood strategy. Tourism Management, 2009, 30(1) : 90-98.

[20］吴承照, 刘广宁. 管理目标与国家自然保护地分类系统. 风景园林, 2017，(7)：16-22.

[21］刘红. 三江源生态移民补偿机制与政策研究. 中南民族大学学报: 人文社会科学版, 2013, 33(6): 101-105.

[22］张浩. 草原生态保护补助奖励机制的贫困影响评价一以内蒙古阿拉善盟左旗为例. 学海, 2015, (6) : 50-56.

[23] 王丹, 黄季焜. 草原生态保护补助奖励政策对牧户非农就业生计的影响. 资源科学, 2018, 40(7): 1344-1353.

[24] 李惠梅, 张安录, 杨欣, 卓玛措. 牧户响应三江源草地退化管理的行为选择机制研究一一基于多分类的 Logistic 模型. 资源科学, 2013, 35(7): 1510-1519.

［25］段伟, 马奔, 秦青, 温亚利. 基于生计资本的农户生态保护行为研究. 生态经济, 2016, 32(8)：180-185.

［26］韩枫, 朱立志. 基于草原生态建设的牧户满意度分析一一甘南草原为例. 农业技术经济, 2017，(3)：120-128.

[27］也尔那孜 -玉山艾力, 邵战林. 基于牧民视角的草原生态保护政策实施效果评价研究——以新疆新源县为例. 中国农业资源与区划, 2017, 38(4): 117-125.

[28］李惠梅, 张安录. 基于结构方程模型的三江源牧户草地生态环境退化认知研究. 草地学报, 2015, 23(4) : 679-688.

[29] 韦惠兰, 贾亚娟, 李阳. 自然保护区林缘社区野生动物肇事损失评估及补偿问题研究. 干旱区资源与环境, 2008, 22(2)：181-186.

[30] 张春丽, 佟连军, 刘继斌. 湿地退耕还湿与替代生计选择的农民响应研究一以三江自然保护区为例. 自然资源学报, 2008, 23(4)： 568-574.

[31］乔斌, 张彦仁, 何泮慧. 精准扶贫背景下自然保护区周边社区发展路径构建一一基于宁夏党家岔湿地自然保护区的案例论证. 资源开发 与市场, 2018, 34(5): 633-637.

[32] Mayring P. Qualitative content analysis. Forum Qualitative Sozialforschung//Forum Social Research, 2000, 1(2), Art. 20, http://nbn-resolving. de/urn: nbn: de:0114-fqs0002204

[33] Hsieh H F, Shannon S E. Three approaches to qualitative content analysis. Qualitative Health Research, 2005, 15(9): 1277- 1288.

[34] 李惠梅, 张雄, 张俊峰, 张安录, 杨海镇. 自然资源保护对参与者多维福祉的影响一一黄河源头玛多牧民为例. 生态学报, 2014,34 (22) : 6767-6777.

[35] 赵晓东. 试论高黎贡山国家级自然保护区的持续发展. 林业经济, 1999, (1): 71-75.

[36] 傅晓莉. 西部自然保护区社区贫困及原因探讨. 林业经济, 2006, (8)：74-76.

[37］李金明. 生态保护、民族生计可持续发展问题研究一以独龙江地区独龙族为例. 云南社会科学, 2008, (3): 81-85.

[38］王昌海, 温亚利, 胡崇德，司开创. 中国自然保护区与周边社区协调发展研究进展. 林业经济问题, 2010, 30(6): 486-492.

[39] 谭静, 冯杰, 汪明. 自然保护区重要过渡带危机及对策研究——基于四川阿坝自治州理县马山村协议保护机制的调研. 林业资源管理, 2011 , (2) : 27-31, 77-77.

[40］邓维杰. 基于社区组织与市场驱动的自然保护区管理方法研究. 四川动物, 2014, 33(3)：466-469.

[41］赵雪峰. 生态环境保护与经济社会发展的协调统一——潘得巴自然保护与社区发展项目为例. 马克思主义与现实, 2014，(2)： 195-200.

[42] 廖凌云, 赵智聪, 杨锐. 基于 6 个案例比较研究的中国自然保护地社区参与保护模式解析. 中国园林, 2017, 33(8): 30-33.

[43] 朱红根, 康兰媛. 退耕还湿农户替代生计选择及其影响因素分析一一以鄱阳湖区为例. 江苏大学学报: 社会科学版, 2017, 19(3): 7-14.

[44] 张建军. 自然保护区生态保护与建设发展研究——山西阳城蟒河猕猴国家级自然保护区为例. 林业经济, 2019, 41(6)：104-109.

[45] 沈孝辉. 草海的自然保护与社区发展. 绿色中国, 2004, (7): 64-66.

[46] 李文军, 马雪蓉. 自然保护地旅游经营权转让中社区获益能力的变化. 北京大学学报: 哲学社会科学版, 2009, 46(5): 146-154.

[47] 马洪波. 探索三江源生态保护与发展的新路径—UNDP-GEF 三江源生物多样性保护项目的启示. 青海社会科学, 2017, (1) : 35-40.

［48］杨明, 骆江玲, 明亮. 论替代生计项目在乡村的发展一一 以 NGO 在三江平原生态保护项目为例. 农村经济, 2010, (4) : 101-104.

[49］张引，杨锐. 中国自然保护区社区共管现状分析和改革建议. 中国园林, 2020, 36(8) : 31-35.

[50] 马䎦艳, 赵雪雁, 兰海霞, 薛冰. 重点生态功能区农户的生计风险多维感知及影响因素——甘南黄河水源补给区为例. 生态学报, 2020, 40(5): 1810-1824. 